DOI: https://doi.org/10.31933/dijms.v2i1 Received: 26 January 2021, Revised: 7 March 2021, Publish: 11 March 2021

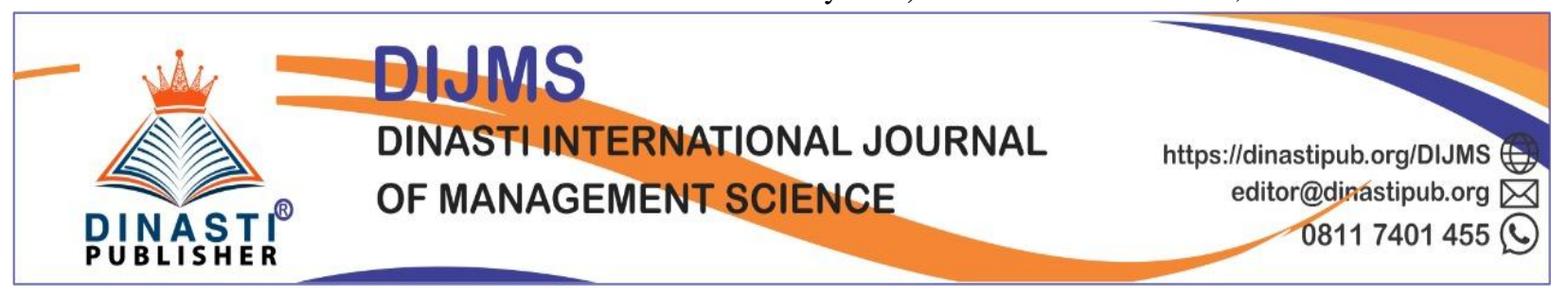

\title{
EFFECT OF VILLAGE APPARATUS PERFORMANCE, INTERNAL CONTROL, INFORMATION TECHNOLOGY UTILIZATION ON VILLAGE FUND ACCOUNTABILITY AND IMPLICATIONS ON QUALITY VILLAGE FINANCIAL REPORT
}

\author{
Budi Hendaris ${ }^{1}$, Romli Romli ${ }^{2}$ \\ 1) Jenderal Ahmad Yani University, Cimahi, Indonesia, budi.hendaris@lecture.unjani.ac.id \\ 2) Jenderal Ahmad Yani, Cimahi, Indonesia, ramli@lecture.unjani.ac.id \\ Corresponding Author: Budi Hendaris
}

\begin{abstract}
Village Fund is a new policy, so it needs good accountability. As a form of responsibility for village fund management, it is necessary to make quality financial statements. This study aims to analyze the effect of village apparatus performance, internal control, and information technology on fund management accountability and its implications for the quality of financial reports. This research used quantitative and retrieval methods using survey techniques. It was conducted using 117 respondents as officials in charge of compiling financial reports in West Bandung Regency villages. Furthermore, data analysis was performed using SEM PLS with PLS 3.0. The results showed that the village apparatus performance, internal control, and information technology use affected fund management accountability and the quality of financial reports. The research results imply that creating quality village financial statements required village apparatus performance, internal control, use of information technology, and fair accountability.
\end{abstract}

Keywords: Village Apparatus Performance, Internal Control, Information Technology, Accountability, Village Financial Statements

\section{INTRODUCTION}

Financial statements are the embodiment of the accountability of an entity that manages finances. Accountable financial statements are financial statements that stakeholders can access (Lai \& Hamilton, 2020). With good responsibility, it is expected that the quality of local government financial statements will increase. To ensure the financial management report has been welded even, effective, reliable, and can predict in the future, and accountability is needed (Purba et al., 2020). At this moment, society is highly demanding the responsibility of the district government (Bustaman et al., 2018)

Accountability of financial statements to local governments in Indonesia every year is Assessing the quality of government information. Good quality local government financial statements are a tangible manifestation of local government accountability given authority in the central government's decision-making. (Yuesti et al., 2020) 
Financial statements are essential and needed to determine the government's use and utilization of budget allocations to carry out government information development activities. Government financial statements need to be assessed to determine the quality of information related to allocation information and budget usage (Ahmad et al., 2020). The following are the Audit Board of the Republic of Indonesia audit results on district governments' financial statements in Indonesia.

Table 1

District Opinion Development of BPK

\begin{tabular}{lrrrrr}
\hline Opinion & 2014 & 2015 & 2016 & 2017 & 2018 \\
\hline Unqualified Opinion & $50 \%$ & $54 \%$ & $66 \%$ & $72 \%$ & $79 \%$ \\
\hline Qualified Opinion & $41 \%$ & $38 \%$ & $29 \%$ & $24 \%$ & $18 \%$ \\
\hline Adversed Opinion & $1 \%$ & $1 \%$ & $5 \%$ & $5 \%$ & $3 \%$ \\
\hline & & & & & \\
Disclaimer of opinion & - & - & - & - & - \\
\hline
\end{tabular}

\section{Source: BPK RI}

Based on the Audit Board of the Republic of Indonesia audit results, the development of quality of financial statements of the district government in Indonesia has not shown optimal results. It can be seen that there are still local governments that obtain advertised opinions. Many local government officials try to bribe auditors to obtain reasonable views without exception, so they got into trouble with the Corruption Eradication Commission.

To improve the quality of good financial statements required accountability, personnel performance, adequate internal control, and information technology utilization.

To prove that accountability, apparatus performance, internal control, and utilization of information technology can improve the quality of financial statements, researchers researched village villages in the West Bandung Regency Government.

Therefore, the purpose of this researcher is to obtain empirical evidence that accountability, apparatus performance, internal control, and utilization of information technology affect the quality of financial statements.

\section{LITERATURE REVIEW}

\section{Village Fund Management Accountability}

A form of accountability of a work program implemented by an organization needs to be made financial statements. Therefore, financial reporting can increase transparency and accountability in the budget process (Carlitz, 2013). Accountability of village fund management is the embodiment of village heads' responsibility to account for the management of village funds to stake holder to achieve the goals set through the media of periodic accountability.

Implementation of accountability by government organizations or institutions is influenced by factors that can support and inhibit, among others: 1) Factors of awareness of officers/employees, 2) Factors of rules, 3) Organizational factors, 4) Factors of ability and skills, and 5) Factors of facilities and infrastructure (Julita \& Susilatri, 2018).

The principle of bureaucratic accountability is a measure that shows how high the level of conformity of service implementation is to the size of external values or norms owned by stakeholders who are interested in the service. , United Nations Development Programme (UNDP) develop a method or way to measure bureaucratic accountability that can be seen from 5 (five) principles of fault this is transparency, liability, controllability, responsibility, and responsiveness (Dana \& Hasniati, 2016). The focus of openness is that the organization in question can present facts about its performance. The principle of obligation is whether there are sanctions for the organization in question if it does not reach the specified target. The code of control is that the organization does what the assigning party wants. The principle of responsibility is that 
organizations have standards of performance. The direction of response is that the organization has met the real expectations of stakeholders.

\section{Quality of Financial Reports}

As a form of accountability from financial managers is to prepare a report. One of them explained how much money was received in the financial statements and how much was spent. In government organizations, to improve the quality of financial statements made by government entities has been created an accounting standard that regulates the preparation of financial statements. The accounting standards are contained in the Government Regulations No. 71 of 2010. The report's quality must meet qualitative financial statements, i.e., relevant, reliable, comparable, and understandable (Dana \& Hasniati, 2016)(PP No 71 Tahun 2010, n.d.). What is meant by the relevant financial statements if the information contained in the financial statements may affect the user's decisions. Reliable financial statements if the data in finance is free from misleading understanding and material errors, the data presented honestly can then be verified. Comparable financial statements mean that the information in the financial statements can be compared with previous reports and can be compared with other entities' financial statements. Financial statements that can be understood mean that the information presented in the financial statements is expressed in forms and terms adjusted to the limits of understanding of the users.

\section{Relationship of Village Apparatus Performance with Accountability of Village Fund Allocation Management}

Performance is the appearance of a person's work or an organization (M. Pananrangi A, 2019). A good organization must have a performance measurement system so that its employees and organization's performance can be measured. Performance measurement results will be beneficial for the organization as a good bait in making the organization's strategic plan. To measure performance levels can use productivity, service, and accountability (M. Pananrangi A, 2019). Productivity is the relationship of input with output in a production process. Thus productivity is a comparison between the results achieved and the resources that have been used to produce these results. To measure the productivity of village apparatus using (1) mental attitude of village officials, (2) ability of village officials, (3) work spirit. To measure the service of village apparatus using service standards (1) Requirements, (2) systems, mechanisms and procedures, (3) service period, (4) cost/tariff, (5) service products, (6) handling complaints, suggestions and entering (M. Pananrangi A, 2019). To measure the accountability of the apparatus's performance is how much the village government's policy following the aspirations of the villagers. The version of the device that has been discussed previously is suspected of having a relationship with the accountability of village funds because the village apparatus is the party that implements the village fund program. Thus the author hypothesizes:

\section{H1: The performance of village government apparatus affects the accountability of village funds}

Relationship of Internal Control With Accountability of Village Fund Management

Suppose the application of an Internal Control System for agencies in the government has been made a guideline in Government Regulation in Government Regulation (PP) No. 60 of 2008, known as the Government Internal Control System (SPIP). Based on the PP No 60 of 2008, SPIP is applied to achieve the objectives of the organization through a necessary process of actions and activities by the leadership, and all employees continue to provide adequate confidence carried out through effective and efficient workouts, reliable financial reporting, the security of state assets and complying with applicable laws and regulations. Based on Government Regulation of the Republic of Indonesia Number 60 the year 2008, internal control is a 
process influenced by human resources (HR) and information technology systems designed to help an organization achieve specific objectives (PP RI No 60 Tahun 2008, n.d.)

Internal control is a way to direct, monitor, measure the resources of an organization, and has a very important role in preventing and detecting embezzlement. Indicators used to calculate the Government Internal Control System's implementation are control environment, risk assessment, control activities, information and communication, and monitoring (PP RI No 60 Tahun 2008, n.d.). Research Results (Arif et al., 2017), who researched villages in Sigi Regency, stated that internal control positively affects village fund allocation management accountability. Research conducted by (Umar et al., 2018), who researched the West Gane sub-district of Maluku, stated that internal control positively affects village fund management accounting. Research conducted by (Budiana et al., 2019) analyzed Enrekang Regency villages, saying that internal control affects village fund management accountability. Based on the description can be hypothesized as follows:

\section{H2: Implementation of Government Internal Control System has a positive effect on Village Fund Accountability \\ Relationship of Information Technology Utilization with Accountability of Village Fund Management}

Information technology used in village fund management has been implemented in village government. The information technology is named with the Application of Village Financial System (Siskeudes). Corruption Eradication Commission (KPK) issued a letter of appeal to the regional heads to manage village funds using Siskeudes application. Siskeudes is a system created by the Financial and Development Supervisory Board (BPKP) that can help the Village Government's financial management. The utilization of Siskeudes in village financial management is carried out by utilizing information technology programs to support the Regional Financial Information System. Siskeudes is used to document, administer, and process village financial management data or other related data into useful information for the community that will serve as the basis for decision-making in planning, implementing, and reporting the village's accountability Government. Indicators used to measure the utilization of Siskeudes are development planning, village financial budgeting, village financial implementation, village financial administration, reporting and accountability, village financial supervision. Thus, if a village government has implemented Siskeudes, it can help improve village fund management accountability. This is in line with the research results (Hendri et al., 2016), which examined the relationship of facilities and infrastructure with village financial management's performance in Central Lombok Regency, showing that facilities and infrastructure have a positive effect on the performance of village fund management. Research results (Sugiarti \& Yudianto, 2017), who researched Karawang Regency, stated that information technology affects village fund management accountability. Research Results (Jannah et al., 2018) the research in Central Lombok noted that information technology has a significant positive effect on village fund management accountability. Based on the description can be hypothesized:

\section{H3: Utilization of information technology affects Accountability of Financial Management of Village Fund Allocation \\ Relationship of Village Apparatus Performance with The Quality of Village Financial Statements}

The village officials in charge of preparing village financial statements are required to perform well. One of the indicators of good performance is that village financial statements are made on time. For the village financial statements to have useful quality information, the village officials who are given the authority to prepare financial statements must have the competence necessary to prepare the financial statements; thus, if the compiler of financial statements has the competencies required so that 
it is expected that the performance is good which in the end the quality of financial statements are made to be better. Based on the explanation can be hypothesized as follows:

\section{H4: The performance of the apparatus affects the quality of financial statements} Relationship of Government Internal Control with The Quality of Village Financial Statements

Qualitative characteristics of financial statements that include relevant, reliable, comparable, and understandable can be realized if there is control in preparing financial information from data entry until the financial statements are successfully made. This thinking is in line with the results of research that has been conducted by (Afiah \& Azwari, 2015), (Hesti Utaminingtyas Akuntansi, 2019), which examines the influence of internal government control on the quality of local government financial statements, the results of which state that internal management of the government affects the quality of local government financial statements. On the basis of such explanations can be hypothesized as follows:

\section{H5: Internal control affects the quality of village financial statements Relationship of Utilization of Information Technology with The Quality of Village Financial Statements}

Following the development of information technology, human work in working in an entity becomes easier. The work that is considered difficult to do by humans is not an obstacle because, with technological advances, it can be overcome. Similarly, it experienced relatively rapid development of the previous manual in preparing financial statements, now already using the application. There is an increase in accuracy when already using the application (software) in terms of data accuracy. The application used in preparing financial statements in the village is the Village Financial System (Siskeudes). With the use of Siskeudes, it is expected that the quality characteristics of village financial statements will be better. This is in line with the research that has been conducted by (Julita \& Susilatri, 2018); the results state that the use of information technology affects the quality of local government financial statements. Based on the explanation can be hypothesized as follows:

\section{H6: Utilization of information technology affects the quality of village financial statements Relationship of Accountability of Village Fund Management with The Quality of Village Financial Statements}

One of the financial statements that must be made by the village government is the financial report of the Implementation of Village Fund Realization. For the financial statements of the implementation of village fund realization to have the quality required in PP No. 71 of 2010, the report must be accountable to stakeholders. Thus the accountability of village funds has a relationship with the quality of village financial statements. This is in line with the results of (Rahmawati 2015), stating that financial statements' accountability affects local government financial statements' quality. Thus can be hypothesized:

\section{H7: Accountability of village funds affects the quality of village financial statements.}

\section{RESEARCH METHODS}

This research type is causal research, a causal design useful for analyzing how a variable affects another variable. The data used in this study is primary data by using questionnaires as an analysis tool.

The population in this study is a village located in West Bandung District. Sampling technique using non-probability sampling with purposive sampling approach, namely sampling process with specific considerations. Purposive sampling is used because the information to be taken comes from sources that are deliberately selected based on the criteria that have been 
determined by researchers, among others: village apparatus that performs accounting/financial functions, villages that have used the Village Financial System (Siskeudes). The samples used in this study were 117 villages obtained using the Slovin formula, out of the total number of villages in West Bandung Regency, amounting to 165 villages.

\section{FINDINGS AND DISCUSSION}

\section{Description Analysis}

Table 2 is a table of achievements of the questionnaire results that have been processed, which describes the state of the variables studied.

Table 2

Questionnaire Results

\begin{tabular}{|c|c|c|c|}
\hline Variable & Average Score & Range & Range \\
\hline Village Apparatus Performance & 4,38 & $4-5$ & Excellent \\
\hline Internal Control & 4,45 & $4-5$ & Excellent \\
\hline $\begin{array}{l}\text { Utilization of } \\
\text { Technology }\end{array}$ & 4,38 & 4- 5 & Excellent \\
\hline Accountability & 4,38 & 4- 5 & Excellent \\
\hline $\begin{array}{l}\text { Quality of Village Financial } \\
\text { Statements }\end{array}$ & 4,46 & 4- 5 & Excellent \\
\hline
\end{tabular}

Source: Primary data

Based on table 2, village apparatus performance, internal control, utilization of information technology, accountability, and quality of financial statements have been excellent, with an average score of $4.38-4.46$.

\section{Measurement Model}

The calculation of the hypothesized full model obtained with Smart PLS 3.8 rocks is presented in figure 1 .

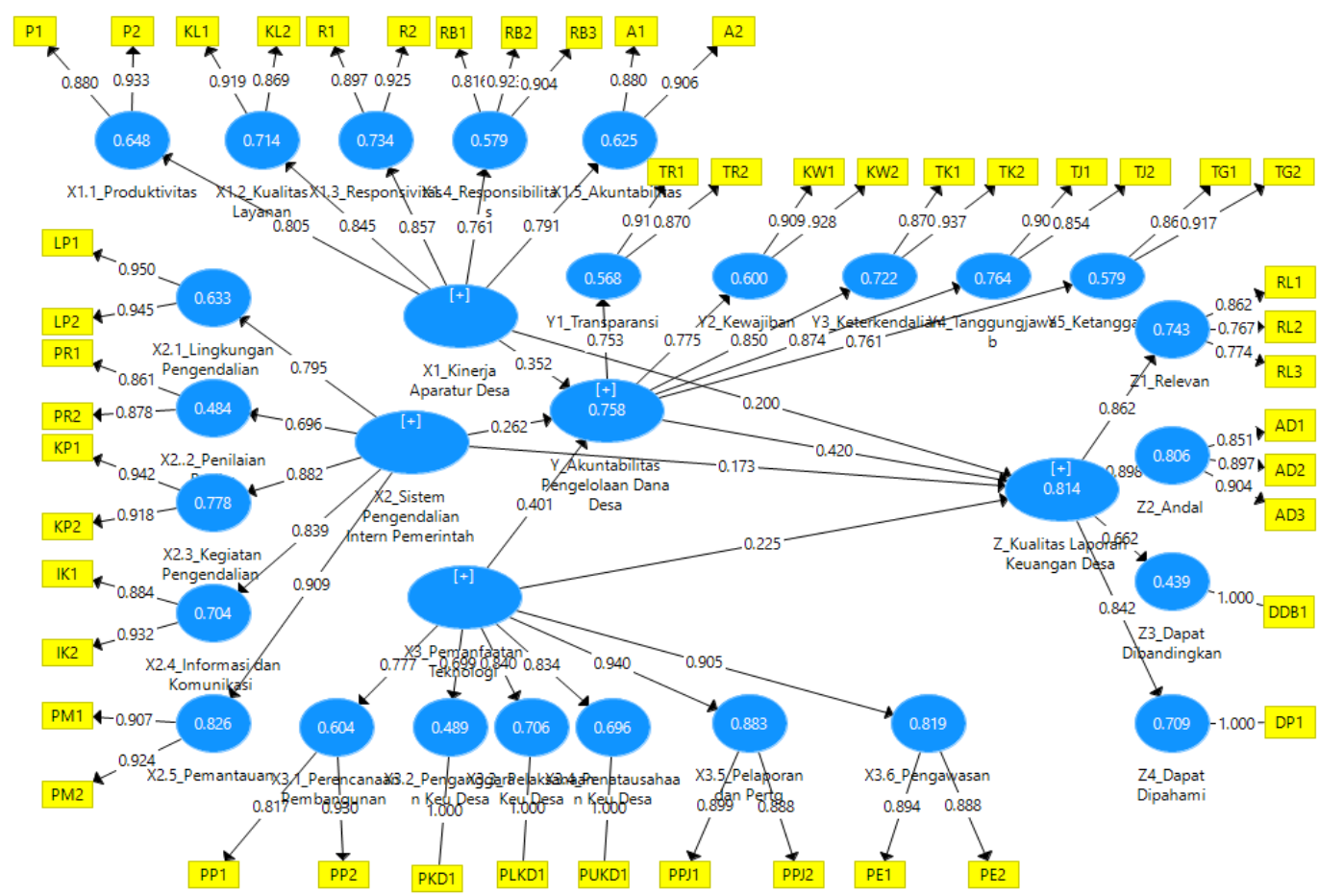

Figure 1 Diagram of the SEM model path approach partial least square (PLS)

There are two models of structural equations for the structure of the research model, figure 1. 


\section{Structural equation model for accountability of village fund management}

Structural equation models for the influence of Village Apparatus Performance, Government Internal Control System, and Utilization of Information Technology on Accountability of village fund management are presented in equation 1 .

$$
\eta_{1}=0,352 \xi_{1}+0,262 \xi_{2}+0,401 \xi_{3}+0,242
$$

The calculation results showed that the influence of village apparatus performance on accountability of village fund management was indicated by the coefficient value of the line of 0.352. The Government's Internal Control System's influence on village fund management's responsibility is indicated by the coefficient value of 0.262 . The effect of Information Technology Utilization on village fund management's accountability is indicated by the coefficient value of 0.401 .

The R-square value for village fund management's accountability variable was obtained by 0.758 , resulting in a model term error of $1-0.758=0.242$.

\section{Structural equation model to the Quality of Village Government Financial Statements}

Structural equation models for the influence of Village Apparatus Performance, Government Internal Control System, Utilization of Information Technology and Accountability of village fund management to the Quality of Village Government Financial Statements are presented in equation 2.

$$
\eta_{2}=0,200 \xi_{1}+0,173 \xi_{2}+0,225 \xi_{3}+0,420 \eta_{1}+0,186
$$

The effect of village apparatus performance on village government financial statements' quality is indicated by the coefficient value of the line of 0.200 . The Government's Internal Control System's influence on the Quality of Village Government Financial Statements is indicated by the line coefficient value of 0.173 . The effect of village apparatus performance on village government financial statements' quality is indicated by the coefficient value of the line of 0.200 . The Government's Internal Control System's influence on the Quality of Village Government Financial Statements is indicated by the line coefficient value of 0.173. The impact of Information Technology Utilization on the Quality of Village Government Financial Statements is indicated by the line coefficient value of 0.225 . The influence of Information Technology Utilization on the Quality of Village Government Financial Statements is indicated by the line coefficient value of 0.420 .

The R-square value for the Village Government Financial Report Quality variable was obtained at 0.814 . This means that the influence of village apparatus performance, internal control, technology utilization, and accountability affects the quality of village financial statements by $81.4 \%$. Model term error of $1-0.814=0.186$ means other factors that are not studied that affect the quality of village financial statements by $18.6 \%$.

\section{Assessment of the size of the structural model f2}

The size effect of $\mathrm{f} 2$ shows the contribution of each construct to the accountability of village fund management. The value of $\mathrm{f} 2$ equals $0.02,0.15,0.35$ can be interpreted that latent variable predictors have small, medium, and large influences (Hair et al., 2016).The calculation result of the size $\mathrm{f} 2$ effect is described in table 3.

Table 3

Assessment of Effect Size Structural Models

\begin{tabular}{cccc}
\hline & & \multicolumn{2}{c}{ f Square } \\
\cline { 3 - 4 } No & Endogenous construct & $\begin{array}{c}\text { Accountability of } \\
\text { Village Fund } \\
\text { Management } \\
(\mathbf{Y})\end{array}$ & $\begin{array}{c}\text { Quality of Village } \\
\text { Financial Statements (Z) }\end{array}$ \\
\hline 1 & $\mathrm{X} 1 \_$Village Performance Apparatus & 0,252 & 0,085 \\
\hline
\end{tabular}




\begin{tabular}{llll}
2 & X2_Government Internal Control System & 0,132 & 0,066 \\
\hline 3 & $\begin{array}{l}\text { X3_Technology Utilization Technology } \\
\text { Utilization }\end{array}$ & 0,410 & 0,120 \\
\hline 4 & $\begin{array}{l}\text { Y_Accountability of Village Fund } \\
\text { Management }\end{array}$ & & 0,230 \\
\hline
\end{tabular}

Source: Primary data

The $\mathrm{f} 2$ value of Village Apparatus Performance is 0.252 (table 3). The value of $\mathrm{f} 2$ between 0.15 0.35 can be expressed effect size for the influence of village apparatus performance on accountability of village fund management is moderate. The f2 value of the Government Internal Control System is 0.132. The value of $\mathrm{f} 2$ between $0.02-0.15$ can be expressed effect size for the Government Internal Control System's influence on accountability of village fund management is small. The $\mathrm{f} 2$ value of Information Technology Utilization is 0.410 . The value of $\mathrm{f} 2$ is more than 0.35 , and then it can be stated effect size for the influence of Information Technology Utilization on Accountability of village fund management is considerable.

The $\mathrm{f} 2$ value of Village Apparatus Performance is 0.085 . The value of $\mathrm{f} 2$ between 0.02 0.15 can be stated effect size for the influence of Village Apparatus Performance on the Quality of Village Financial Statements is small. The f2 value of the Government Internal Control System is 0.066. The value of $\mathrm{f} 2$ between $0.02-0.15$ can be expressed effect size for the Government Internal Control System's influence on the Quality of Village Financial Statements is small. The f2 value of Information Technology Utilization is 0.120 . The value of f2 between $0.02-0.15$ can be expressed effect size for the influence of Information Technology Utilization on the Quality of Village Financial Statements is small. The $\mathrm{f} 2$ value of accountability of village fund management is 0.230 . The value of $\mathrm{f} 2$ between $0.15-0.35$ can be expressed effect size for the effect of village fund management's responsibility on the quality of village government financial statements is moderate.

\section{Hypothesis Testing}

The following are the results of hypothetical testing as found in figure 2 below:

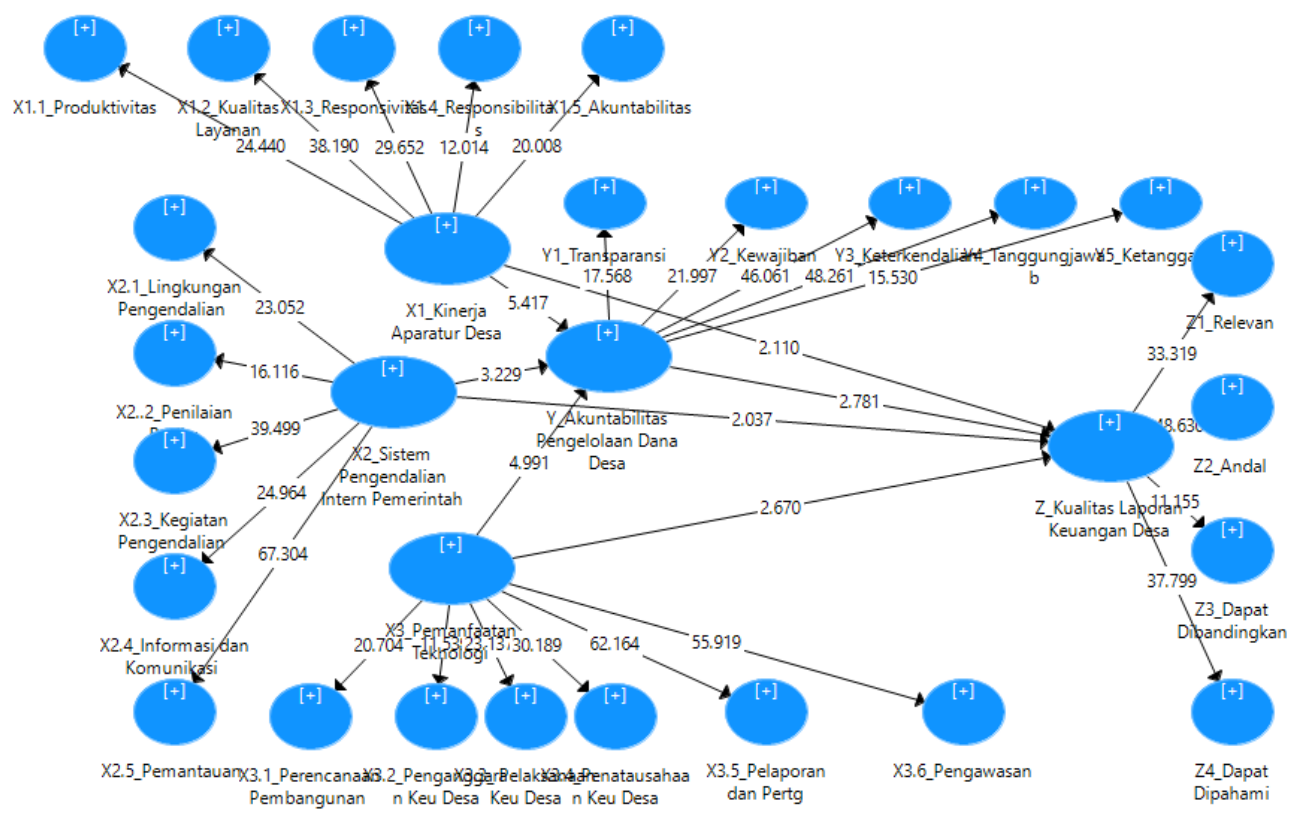

Figure 2: Structural Model static t value

The limit for rejecting and accepting the proposed hypothesis is if the value of $t$ is greater than the table or the p-value is small than 0.05 . The idea will be dismissed or accept the zero hypotheses 
(H0). Table t value of 1,980 . The decision to accept or reject the data hypothesis is seen in the following tables 4 and 5 .

\begin{tabular}{|c|c|c|c|c|}
\hline \multicolumn{5}{|c|}{ Direct Influence Hypothesis Test Results } \\
\hline Hypothesis & Path Coefficient & $\mathrm{t}$ Count & P-value & Conclusion \\
\hline $\begin{array}{l}\text { X1_ Village Apparatus Performance }->Y_{-} \\
\text {Accountability of Village Fund Management }\end{array}$ & 0,352 & 5,417 & 0,000 & Significant \\
\hline $\begin{array}{l}\text { X2_ Government Internal Control System }->Y_{-} \\
\text {Accountability of Village Fund Management }\end{array}$ & 0,262 & 3,229 & 0,002 & Significant \\
\hline $\begin{array}{c}\text { X3_ Technology Utilization -> Y_ Accountability of } \\
\text { Village Fund Management }\end{array}$ & 0,401 & 4,991 & 0,000 & Significant \\
\hline $\begin{array}{c}\text { X1_ Village Apparatus Performance -> Z_ Quality of } \\
\text { Village Financial Statements }\end{array}$ & 0,200 & 2,110 & 0,037 & Significant \\
\hline $\begin{array}{l}\text { X2_ Government Internal Control System }->Z_{-} \\
\text {Quality of Village Financial Statements }\end{array}$ & 0,173 & 2,037 & 0,044 & Significant \\
\hline $\begin{array}{c}\text { X3_ Technology Utilization -> Z_ Quality of Village } \\
\text { Financial Statements }\end{array}$ & 0,225 & 2,670 & 0,009 & Significant \\
\hline $\begin{array}{c}\mathrm{Y}_{-} \text {Accountability of Village Fund Management -> } \\
\mathrm{Z}_{-} \text {Quality of Village Financial Statements }\end{array}$ & 0,420 & 2,781 & 0,006 & Significant \\
\hline
\end{tabular}

Source : Primary Data

Based on table 4, the hypothetical test results show that the relationship of village apparatus performance variables with the accountability of village fund management is indicated by the coefficient value of the path of 0.352 with a count value of $5,417 \mathrm{p}$-values of 0.000 . The $\mathrm{t}$ statistical value obtained is greater than the t-critical $(1,980)$, and the p-value $(0.000)$ is less than the alpha value of 0.05 . This result means that the performance of the village apparatus affects the accountability of village fund management. The variable relationship of the government's internal control system with village fund management's responsibility is indicated by the coefficient value of 0.262 with the at-count value of 3.229 and a p-value of 0.002 . The t-statistical value obtained is more excellent than the critical $(1,980)$, and the p-value $(0.002)$ is less than the alpha value of 0.05 . This result means that the government's internal control system affects the accountability of village fund management. The variable relationship of village apparatus performance with village government financial statements' quality is indicated by the line coefficient value of 0.200 with the at-account value of 2,110 and a p-value of 0.037 . The t-statistical value obtained is more excellent than the critical $(1,980)$, and the p-value $(0.037)$ is less than the alpha value of 0.05 . This result means that the Performance of Village Apparatus affects the Quality of Village Government Financial Statements. The variable relationship of Government Internal Control System with Accountability of village fund management is indicated by the path coefficient value of 0.173 with the at-count value of 2.037 and a p-value of 0.044 . The t-statistical value obtained is more excellent than the critical $(1,980)$, and the p-value $(0.044)$ is less than the alpha value of 0.05 . These results mean that the Government Internal Control System affects the Quality of Village Government Financial Statements. The variable relationship of Information Technology Utilization with The Quality of Village Government Financial Statements is indicated by the line coefficient value of 0.225 with the at-count value of 2,670 and $p$-value of 0.009 . The t-statistical value obtained is more excellent than the critical $(1,980)$, and the p-value $(0.009)$ is less than the alpha value of 0.05 . This result means that the Utilization of Information Technology affects the Quality of Village Government Financial Statements. The variable relationship of village fund management accountability with village government financial statements' quality is indicated by the line coefficient value of 0.420 with an at-count of 2,781 and a p-value of 0.006 . The t-statistical value obtained is greater than the critical $(1,980)$, and the p-value is less $(0.006)$ than the alpha value of 0.05 . This result means that accountability of village fund management affects the quality of village government financial statements. 
Table 5

Indirect Influence Test Results

\begin{tabular}{|c|c|c|c|c|c|}
\hline & $\begin{array}{l}\text { Original } \\
\text { Sample } \\
(\mathrm{O})\end{array}$ & $\begin{array}{l}\text { Sample } \\
\text { Mean } \\
\text { (M) }\end{array}$ & $\begin{array}{l}\text { Standard } \\
\text { Deviation } \\
\text { (STDEV) }\end{array}$ & $\begin{array}{l}\text { T Statistics } \\
(|\mathrm{O} / \mathrm{STDEV}|)\end{array}$ & $\begin{array}{c}\mathrm{P} \\
\text { Values }\end{array}$ \\
\hline $\begin{array}{c}\text { X1_ Village Apparatus } \\
\text { Performance -> Z_Quality of } \\
\text { Village Financial Statements } \\
\text { X2 Government Internal }\end{array}$ & 0,148 & 0,147 & 0,064 & 2,312 & 0,023 \\
\hline $\begin{array}{c}\text { Control System -> Z_Quality of } \\
\text { Village Financial Statements }\end{array}$ & 0,110 & 0,110 & 0,053 & 2,072 & 0,040 \\
\hline $\begin{array}{c}\text { X3_Technology Utilization -> } \\
\text { Z_Quality of Village Financial } \\
\text { Statements }\end{array}$ & 0,168 & 0,160 & 0,067 & 2,497 & 0,014 \\
\hline
\end{tabular}

Source: Primary data

Based on table 5, the indirect influence test of the influence of village apparatus performance on village financial statements' quality through accountability of village fund management shows the value of the influence coefficient of 0.148 with the at-statistics value of $2,312 \mathrm{p}$-value $=0.023$. The t-statistical value obtained is more significant than arthritis $(1,980)$, and the p-value (0.023) is less than the alpha value of 0.05 . This result means that the performance of village apparatus through village fund management accountability has a significant influence on the quality of village financial statements. The impact of the government's internal control system on village financial statements' quality through village fund management's accountability is indicated by the coefficient of influence of 0.110 with the t-statistics value of 2.072 and $\mathrm{p}$-value $=$ 0.040. The t-statistical value obtained is more excellent than the critical $(1,980)$, and the p-value (0.040) is less than the alpha value of 0.05. These results mean that the Government Internal Control System through Accountability of Village Fund Management has a significant influence on the Quality of Village Financial Statements. The effect of Information Technology Utilization on the Quality of Village Financial Statements through Accountability of Village Fund Management is indicated by the coefficient of influence of 0.168 with the t-statistics value of 2,497 and p-value $=0.014$. The t-statistic obtained value is more excellent than the critical $(1,980)$, and the p-value (0.014) is less than the alpha value of 0.05 . This result means that the Utilization of Information Technology through the Accountability of Village Fund Management has a significant effect on the Quality of Village Financial Statements.

\section{CONCLUSION AND RECOMMENDATION}

Village apparatus performance, internal control, information technology, accountability, and quality of village financial statements are in the excellent category-village apparatus performance, affecting village fund management's responsibility. Internal control affects the accountability of village fund management, by the results of (Arif et al., 2017), (Achyani, 2019), (Umar et al., 2018), (Budiana et al., 2019). The use of information technology significantly affects the accountability of village fund management, according to the research (Hendri et al., 2016), (Sugiarti \& Yudianto, 2017), (Jannah et al., 2018). The performance of the village apparatus affects the quality of village financial statements. According to the results of research, internal control affects the quality of village financial statements (Julita \& Susilatri, 2018). The use of information technology and accountability have a significant effect on the quality of village financial statements, according to research results (Rahmawati, 2015).

The research results imply that creating quality village financial statements required village apparatus performance, internal control, use of information technology, and fair accountability. 


\section{REFERENCE}

Achyani, F. (2019). The Determinat Accountability Of Village Funds Management (Study in the Villages in Wonogiri District). Riset Akuntansi Dan Keuangan Indonesia, Vol 4, No 2 (2019), 118-135. https://doi.org/10.23917/reaksi.v4i2.8521

Afiah, N. N., \& Azwari, P. C. (2015). The Effect of the Implementation of Government Internal Control System (GICS) on the Quality of Financial Reporting of the Local Government and its Impact on the Principles of Good Governance: A Research in District, City, and Provincial Government in Sou. Procedia - Social and Behavioral Sciences, 211, 811-818. https://doi.org/10.1016/j.sbspro.2015.11.172

Ahmad, I., Mahfudnurnajamuddin, ., Mas'ud, M., \& Suriyanti, . (2020). Competencies of Apparatus and Internal Control System Effect on The quality of Financial Statement Information and Good Governance. European Journal of Business and Management Research, 5(4), 1-6. https://doi.org/10.24018/ejbmr.2020.5.4.425

Arif, Novita, L., \& Diarespati. (2017). Pengaruh kompetensi dan sistem pengendalian internal terhadap akuntabilitas pemerintah desa dalam mengelola alokasi dana desa (ADD). Jurnal Berkala Akuntansi Dan Keuangan Indonesia, 02(02), 1-20.

Budiana, D. A., Said, D., \& -, N. (2019). the Effect of Village Device Competencies and Internal Control System on Accountability of Village Management. Scientific Research Journal, VII(I), 10-20. https://doi.org/10.31364/scirj/v7.i1.2019.p0119599

Bustaman, B., Amalia, E., \& Jalaluddin, J. (2018). A Performance Analysis of Village Fund Management: A Case Study in Lut Tawar District - Indonesia. Journal of Accounting Research, Organization and Economics, 1(2), 112-121. https://doi.org/10.24815/jaroe.v1i2.11675

Carlitz, R. (2013). Improving transparency and accountability in the budget process: An assessment of recent initiatives. Development Policy Review, 31(S1), 49-67. https://doi.org/10.1111/dpr.12019

Dana, P., \& Hasniati, D. (2016). Model Akuntabilitas. JUrnal Analisis Kebijakan Dan Pelayanan Publik, 2(1), 15-30.

Hair, J. F., Tomas, G. H., \& Sarstedt, M. (2016). Partial least squares structural equation modeling with R. In Practical Assessment, Research and Evaluation (Vol. 21, Issue 1).

Hendri, S., Putu, N., Ayu, C., Rakhmawati, I., \& Atikah, S. (2016). Keuangan Desa di Kabupaten Lombok Tengah. 544-554.

Hesti Utaminingtyas Akuntansi, T. (2019). Factors Affecting Quality of Village Financial Statement. KnE Social Sciences, 3(11), 622. https://doi.org/10.18502/kss.v3i11.4040

Jannah, R., Handajani, L., \& Firmansyah, M. (2018). The Influence of Human Resources, Use of Information Technology and Public Participation to the Transparancy and Accountability of Village Financial Management. International Journal of Scientific Research and Management, 6(5), 373-385. https://doi.org/10.18535/ijsrm/v6i5.em03

Julita, \& Susilatri. (2018). Analysis of factor affecting the quality of government financial report 
Bengkalis regency. International Journal of Scientific and Technology Research, 7(2), 157164.

Lai, J. Y., \& Hamilton, A. (2020). For whom do NGOs speak? Accountability and legitimacy in pursuit of just environmental impact assessment. Environmental Impact Assessment Review, 82(August 2019), 106374. https://doi.org/10.1016/j.eiar.2020.106374

M. Pananrangi A. (2019). Kinerja Pemerintah Dalam Pelayanan Administrasi Kependudukan Di Desa Siawung Kecamatan Barru Kabupaten Barru. Meraja Journal, 2(1), 69-82.

PP No 71 Tahun 2010. (n.d.). Peraturan Pemerintah Tentang Standar Akuntansi Pemerintah.

PP RI No 60 Tahun 2008. (n.d.). Peraturan Pemerintah Republik Indonesia Tentang SPIP. Retrieved February 15, 2020, from http://www.bpkp.go.id/public/upload/unit/sakd/files/PP60Tahun2008_SPIP.pdf

Purba, H., Kurniawati, E., \& Jamain, T. H. (2020). Analysis of Factors Affecting The Accountability of Village Fund Allocation Management (Case Study at the Village Office in Pangandaran District Pangandaran Regency). International Journal of Economics and Management Studies, 7(3), 179-188. https://doi.org/10.14445/23939125/ijems-v7i3p123

Rahmawati, D. (2015). Pengaruh Akuntabilitas dan Transparasi Laporan Keuangan Pemerintah Daerah Terhadap Kualitas Laporan Keuangan Pemerintah Daerah (Studi Kasus Pada Pemerintahan Provinsi Jawa Barat). https://repository.widyatama.ac.id/xmlui/handle/123456789/5558

Sugiarti, E., \& Yudianto, I. (2017). Analisis Faktor Kompetensi Sumber Daya Manusia , Pemanfaatan Teknologi Informasi, dan Partisipasi Penganggaran Terhadap Akuntabilitas Pengelolaan Dana Desa (Survei Pada Desa-Desa di Wilayah Kecamatan Klari , Kecamatan Karawang Timur, Kecamatan Majalaya. Proceedings, 3, 580-590.

Umar, H., Usman, S., \& Purba, R. B. R. (2018). The influence of internal control and competence of human resources on village fund management and the implications on the quality of village financial reports. International Journal of Civil Engineering and Technology, 9(7), 15261531. http://www.iaeme.com/IJCIET/index.asp

Yuesti, A., Adnyana, I. M. D., \& Pramesti, I. G. A. A. (2020). Management information systems and the quality of financial statements in local government. Journal of Public Affairs, September. https://doi.org/10.1002/pa.2462 